\title{
Build your skills
}

\section{Attend an ACRL preconference}

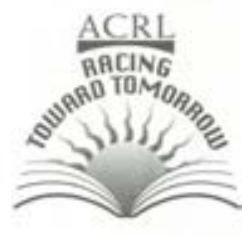

Attend a full-day preconference on Thursday, April 8 , at ACRL's 9th National Conference in Detroit, and develop your skills on a specific topic such as leadership, instruction, telecommunications, patents/copyright, and networks. Details about each preconference are below. A registration form may be found on the Web at http://www.ala.org/acrl/prendex.html.

\section{ACRL Leadership Institute: Build Your Leadership Toolkit (in partnership with EBSCOInformation Services)}

Get the practical skills you need for the next millennium. At this institute you will develop a personal leadership toolkit of techniques, tactics, and strategies. You may attend 3 of the following sessions:

(a) "How to Get What You Want: Refining Your Persuasion/Negotiation Skills"_-Susan K. Martin, university librarian, Georgetown University

(b) "Implementing Change: Skills to Survive and Thrive,"-Sheila Creth, university librarian, University of Iowa

(c) "Motivating and Managing a Team,"Charles Apple, chair, Communication Department, University of Michigan-Flint

(d) "Spreading the Word: Tips for Effective Presentations,"-Linda Wallace, director, ALA's Public Information Office

(e) "Meetings: How to Get Things Done,"Elaine Didier, interim director, Academic Outreach, University of Michigan

Robert Wedgeworth, university librarian, University of Illinois, and Steve Gilbert, TLTR/ American Association of Higher Education, will give keynote addresses. Wedgeworth will ad- dress the many areas in which librarians will need to lead, now and in the future. Gilbert will address the leadership role librarians will take both on and off campus as technology continues to evolve.

\$150 ACRL; \$195 ALA; \$250 nonmember; \$75 student

\section{Learning to Teach}

Based on the ACRL publication Learning to Teach, this workshop gives you both practical and theoretical tips to improve your teaching. You may attend 4 of these sessions: (f) The one-shot lecture"-Esteban Valdez, University of California, San Diego

(g) "Selecting a teaching technique"-Lisa Janicke Hinchliffe, Illinois State University

(h) "Presentation skills/classroom management,"-Mary Pagliero Popp, Indiana University

(i) "Evaluation,"-Lynn Westbrook, Texas Women's University

(j) "Developing effective library assignments,"-Christina Woo, University of California-Irvine

(k) "Instruction in a multicultural/multiracial environment"-Deborah Hollis, Univ. of Colorado

\$130 ACRL; \$180 ALA; \$205 nonmember; \$70 student

\section{Leadership and Learning in the 21st- Century Academic Library}

This workshop will explore key strategies for thriving in a world of accelerating change, including a commitment to learning as an integrated discipline practiced in day-to-day work performance; discovering your leadership power; developing new ways of thinking and behaving; and tapping your creative potential. Presenters: Maureen Sullivan, organizational consultant, and Shelley Phipps, assistant dean, University of Arizona

\$105 ACRL; \$155 ALA; \$195 nonmember; \$70 student 


\section{Enhance Your Performance: Using Myers-Briggs at Work}

Find out your Myers-Briggs Type Indicator and learn how you can use your personality traits to enhance your performance. Learn how to exploit the strengths of your preferred type and discover your particular challenges. Develop your skills in managing yourself and others. Presenter: Mary Devlin, Mary Devlin Associates

\$105 ACRL; \$155 ALA; \$195 nonmember; \$70 student

\section{Assessing the Academic Networked Environment}

Based on the Coalition for Networked Information (CNI) program, this workshop provides both an overview of assessment techniques as well as hands-on experience in developing assessment measures. Covers lessons learned from the institutions participating in CNI's assessment project, selecting measurement techniques, data collection and interpretation, administrative and partnering issues, and using the results for planning, and interpreting data. Presenters: Charles McClure, distinguished professor, Syracuse University; Joan Lippincott, associate executive director, $\mathrm{CNI}$; Betsy Wilson, associate director of libraries, Steve Hiller, head, Science Libraries, and Nana Lowell, associate director of the Office of Educational Assessment, University of Washington

\$150 ACRL; \$210 ALA; \$275 nonmember; \$75 student

\section{Patents, Copyrights, and Trade Secrets}

Trademarks, domain names, copyrights. Which reference questions can you answer without crossing the line and giving legal advice? Learn about these intellectual property issues, relevant Web sites, and the resources of the Great Lakes Patent and Trademark Center, one of only three libraries to have a partnership agreement with the U.S. Patent and Trademark Office. Presenters: Celeste B. Choate, Great Lakes Patents \& Trademark Center; Matthew J. Russo, Michael Stewart, and Richard D. Grauer, Rader, Fishman \& Grauer, P.L.L.C.

\$75 ACRL; \$105 ALA; \$150 nonmember; \$50 student

\section{Telecommunications 101 for Librarians}

Learn about the key telecommunications issues that affect you on campus and how to create and manage campuswide information systems: telecommunications networks, exchange and interexchange carriers, and the telecom- munications infrastructure. Presenter: Ruth A. Michalecki, director of telecommunications, University of Nebraska-Lincoln

\$105 ACRL; \$150 ALA; \$195 nonmember; $\$ 70$ student

\section{Turbo-Charge Your Coaching Skills (offeredby Reference and User Services Association of ALA)}

Coaching will be one of the most necessary competencies as work is done in more collaborative ways. Learn and practice coaching skills for use with peers, in work groups or teams, with direct-reports, and when in a mentoring relationship. Explore several coaching methods that will help you in performance review, accountability, and conflict resolution. Presenters: Kathryn Deiss, program manager, Association of Research Libraries and Karen Liston, head of Resource Access, University of Washington

\$135 RUSAACRL; \$180 ALA; \$230 nonmember; \$70 student

\section{Designing and Building Leading Edge Libraries}

Gain practical advice for developing or renovating a library that will easily integrate the new technologies and provide space for maintaining core services. Learn about design and storage considerations, the planning process, network design, and designing and building the facility. Tour the brand new library at Eastern Michigan University as part of this preconference. Presenters: Morell D. Boone, Dean of learning resources and technologies, and Sandra Yee, department head, University Library, Eastern Michigan University

\$105 ACRL; \$150 AlA; \$195 nonmember; \$70 student

\section{Advance registration}

Register for ACRL's 9th National Conference, "Racing Toward Tomorrow," by March 12, 1999, and save nearly $15 \%$ off onsite rates. The conference, April 8-11, 1999, in Detroit, will allow you to keep pace and provide leadership for the future direction of academic libraries. More than 200 programs will explore issues such as scholarly communication, information literacy, distance learning, electronic publishing, alternate funding sources, etc.

Registration materials are on the Weh at http://www.ala.org/acrl/prendex.html. Or call (800)545-2433 x2514 to request registration materials. 

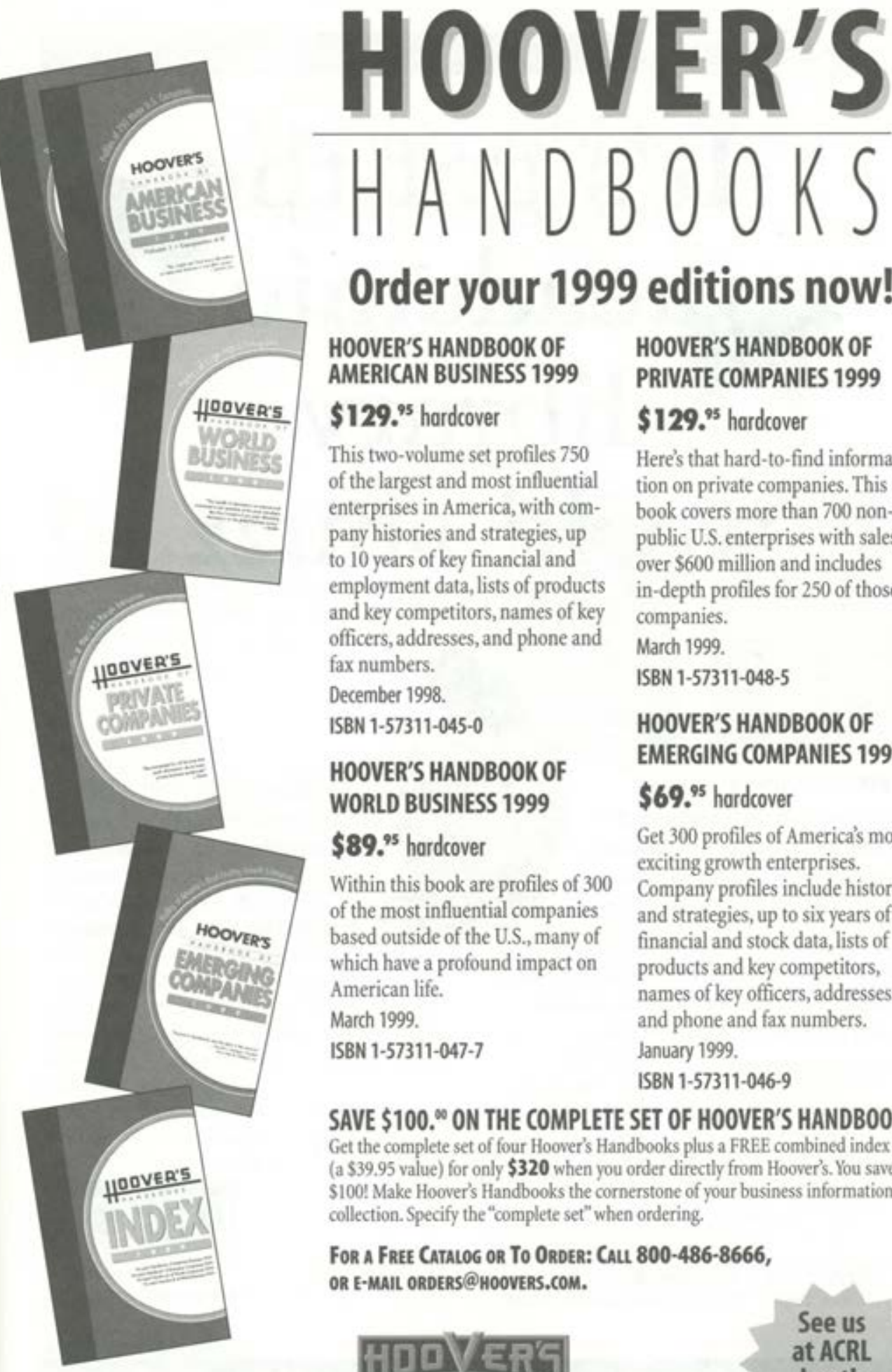

\section{Order your 1999 editions now!}

\section{HOOVER'S HANDBOOK OF AMERICAN BUSINESS 1999 \\ \$129.95 hardcover}

This two-volume set profiles 750 of the largest and most influential enterprises in America, with company histories and strategies, up to 10 years of key financial and employment data, lists of products and key competitors, names of key officers, addresses, and phone and fax numbers.

December 1998.

ISBN 1-57311-045-0

\section{HOOVER'S HANDBOOK OF WORLD BUSINESS 1999}

\$89.95 hardcover

Within this book are profiles of 300 of the most influential companies based outside of the U.S., many of which have a profound impact on American life.

March 1999.

ISBN 1-57311-047-7

HOOVER'S HANDBOOK OF PRIVATE COMPANIES 1999

\section{$\$ 129.9^{95}$ hardcover}

Here's that hard-to-find information on private companies. This book covers more than 700 nonpublic U.S. enterprises with sales over $\$ 600$ million and includes in-depth profiles for 250 of those companies.

March 1999.

ISBN 1-57311-048-5

\section{HOOVER'S HANDBOOK OF EMERGING COMPANIES 1999}

$\$ 69 . .^{95}$ hordcover

Get 300 profiles of America's most exciting growth enterprises.

Company profiles include histories and strategies, up to six years of key financial and stock data, lists of products and key competitors, names of key officers, addresses, and phone and fax numbers.

January 1999.

ISBN 1-57311-046-9

\section{SAVE $\$ 100 .^{\infty}$ ON THE COMPLETE SET OF HOOVER'S HANDBOOKS} Get the complete set of four Hoover's Handbooks plus a FREE combined index (a $\$ 39.95$ value) for only $\$ \mathbf{3 2 0}$ when you order directly from Hoover's. You save $\$ 100$ ! Make Hoover's Handbooks the cornerstone of your business information collection. Specify the "complete set" when ordering.

For a Free Catalog or To Order: Call 800-486-8666, ORE-MAIL ORDERS@HOOVERS.COM.

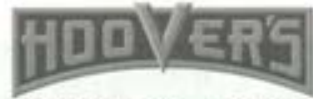

BUSINESS PRESS
See us at ACRL booth \#238 


\section{It's

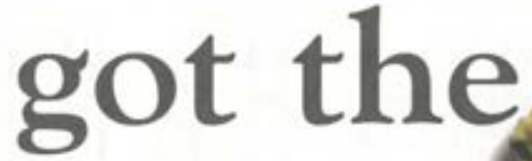

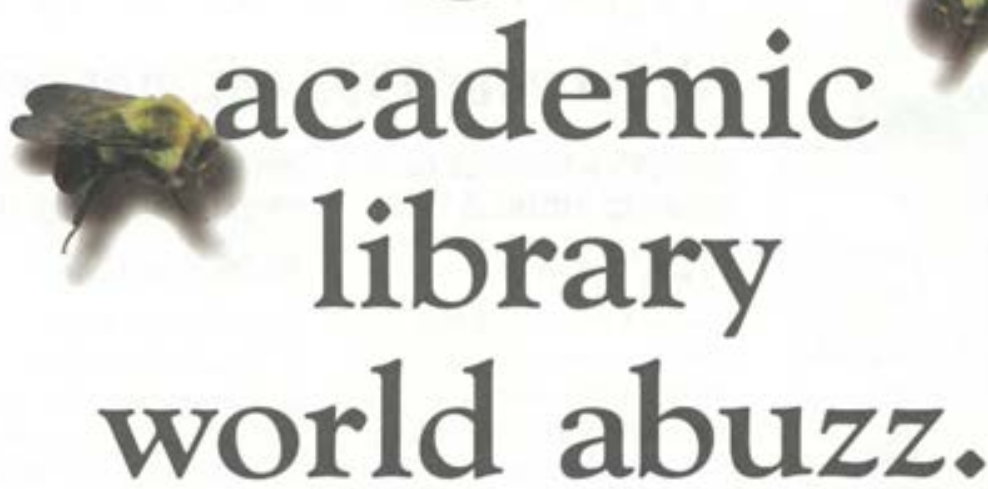

EBSCO Online", the new

electronic serials management tool from EBSCO Subscription Services, is creating quite a buzz in academic libraries. From its easy-to-use administrative

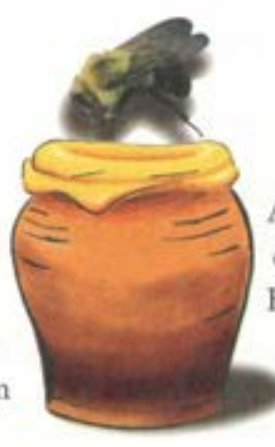

Administrators can even select certain journals for certain people. How's that for bee-ing flexible?

EBSCO Online. It's a honey. features to its intuitive search options, EBSCO Online is redefining the way people think of electronic journal access and management.

All the subscription formats you need and want from a name you already know and trust. 